\title{
Wastewater disposal at safari lodges in the Okavango Delta, Botswana
}

\author{
TS McCarthy ${ }^{1 *}$, T Gumbricht ${ }^{1}$, RG Stewart ${ }^{2}$, D Brandt ${ }^{1}$, PJ Hancox ${ }^{1}, \mathrm{~J} \mathrm{McCarthy}^{1}$ and AG Duse ${ }^{2}$ \\ ${ }^{1}$ Department of Geology, School of Geosciences, University of the Witwatersrand, PO Box 3, WITS 2050, Johannesburg, South Africa \\ 2 National Health Laboratory Service, University of the Witwatersrand Medical School, PO Box 2115, Houghton 2014, \\ Johannesburg, South Africa
}

\begin{abstract}
Many safari lodges in the Okavango Delta obtain their water supply from boreholes in near-surface aquifers while disposing of their wastewater via soak-aways, creating a potential risk of contamination of their water supply. Most islands in the Delta contain sites where the groundwater has become salinised as a result of transpiration by island vegetation. This study of wastewater disposal at such a site on Chitabe Island, which involved surveying of the water table, measurement of groundwater salinity, field bacteriological screening and groundwater flow modelling has revealed that although water disposal has created a recharge mound, the depression in the water table induced by transpiration by island vegetation is such that pollutants will remain confined to the region of maximum groundwater depression. Although the soils are sandy, they exhibit significant filtration effects on bacteria. The field assay used in this study was unable to detect coliform and $E$. coli bacteria in groundwater within a distance of $20 \mathrm{~m}$ from the disposal point. Modelling of groundwater flows indicates that boreholes located on the outer fringes of the island are secure from contamination. The study suggests that disposal of wastewater into areas where the groundwater is salinised provides a sustainable solution to the problem of wastewater disposal in the Okavango Delta.
\end{abstract}

Key words: Okavango Delta; wastewater disposal; field bacteriological screening

\section{Introduction}

The Okavango Delta of northern Botswana (Fig. 1) has become an important international tourist destination. The mixed terrain found in the seasonal swamps, which combines shallow wetland environments with densely forested islands, is a particularly popular region for siting safari lodges, and most of the lodges have been built in the dense, riverine forest on these islands. The majority of lodges obtain their water from boreholes on the island close to the lodge, and wastewater is treated and disposed of by means of septic tanks connected to french drains or soak-aways, also close to the lodge. Over most of the seasonal swamps, the water table is very shallow, and the wastewater soaks only a short distance, usually 2 to $3 \mathrm{~m}$, before encountering the groundwater table. The soils of the Delta are dominated by aeolian sands of the Kalahari Group. Lodges typically accommodate between 16 and 24 guests, and the ratio of staff to guests is usually about 2, so that at full occupancy, a lodge may entail a community of up to 75 people. The quantity of wastewater generated can therefore be quite large, and for the bigger camps may exceed $15 \mathrm{~m}^{3} \cdot \mathrm{d}^{-1}$. In addition, most lodges dispose of organic refuse in pits in the general camp area. These pits are typically about $2 \mathrm{~m}$ deep, and close to the water table.

The close proximity of water draw-points to wastewater and other refuse disposal sites in an environment of shallow groundwater and sandy soils creates a potential risk of contamination of the water supply by inorganic and organic contaminants (e.g. diesel fuel) and particularly by pathogens. Parker and Mee (1982), for example, found that Salmonella spp. and fecal coliforms could

\footnotetext{
* To whom all correspondence should be addressed.

ofi +2711 717 6547; fax: +2711 339 1697;

e-mail: whitfieldl@geosciences.wits.ac.za

Received 16 October 2002; accepted in revised form 28 August 2003.
}

survive for longer than $64 \mathrm{~d}$, the duration of their experiments, in shallow aeolian sand aquifers similar to those of the Okavango Delta. Olanrewaju (1990) has reviewed the problems associated with disposal of outflow from septic tanks. Although septic tanks are claimed by manufacturers to remove most (some claim all) pathogens, this situation is rarely, if ever, attained in normal use, and especially in remote areas, where proper routine maintenance of the tanks cannot be carried out. Micro-organisms are released in large numbers in the outflow, and can enter the groundwater, especially if the water table is shallow. Survival and dispersal in the groundwater environment is also highly variable, and $E$. coli have been reported to have moved as much as $46 \mathrm{~m}$ vertically and $70 \mathrm{~m}$ horizontally in an aquifer under favourable conditions. At Fort Devens, Massachusetts, enteroviruses have been detected in groundwater $183 \mathrm{~m}$ from a wastewater point source. Viruses in particular are believed to be removed from wastewater by adsorption, especially by clays. Low-clay, sandy soils, such as those in the Okavango region would probably have a relatively low adsorption capacity. In addition to contamination, there is the added risk of eutrophication. Wastewater, especially sewage, is rich in nutrients, and its escape into the environment could lead to local eutrophication, particularly given the hyperoligotrophic status of the Okavango Delta ecosystem (Cronberg et al., 1995). Such eutrophication of surface water arising from septic tank soak-away effluent has been recorded elsewhere (e.g. Wall and Webber, 1970).

Although there are potential risks associated with the subsurface disposal of wastewater in the Okavango Delta, there are no other alternatives. Surface disposal, such as in specially created wetland areas, is out of the question, because of the very real danger that large animals such as elephants and hippopotami could spread pathogens from these created disposal sites into the wetland at large. Realising this, McCarthy et al. (1994) proposed a strategy to reduce the potential risk associated with subsurface wastewater 


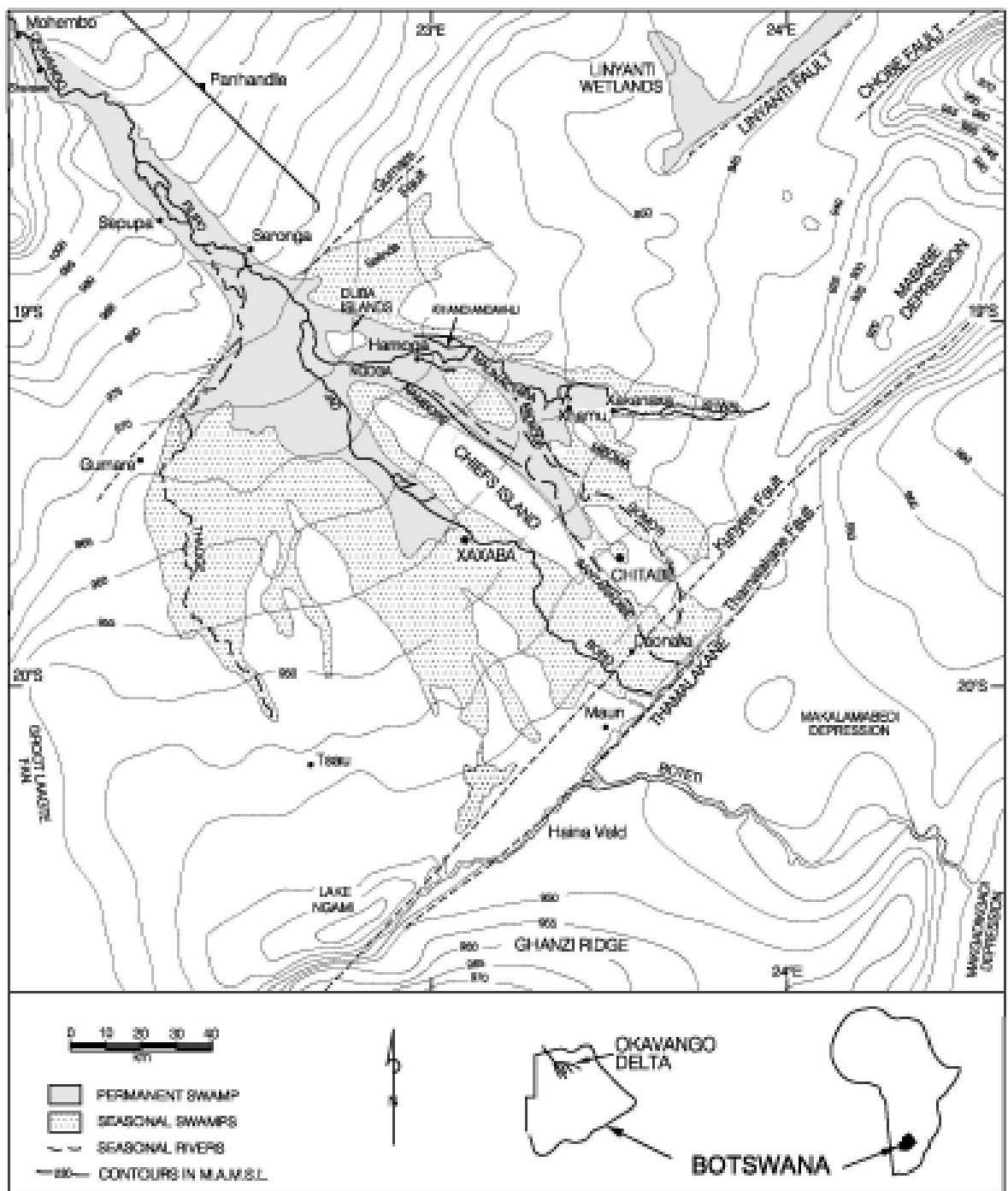

Figure 1

Location of Chitabe Island disposal in the Okavango Delta. They had observed that the groundwater table beneath most islands is lowered relative to the surrounding swamp water level as a result of transpiration by the large trees which grow around the island fringes. Dissolved salts (mainly sodium bicarbonate) accumulate in the groundwater in the centre of the groundwater depression, and groundwater salinity is typically high, up to $50000 \mathrm{mg} \cdot \ell^{-1}$. They suggested that wastewater disposal points should be sited directly above these saline areas, so that the wastewater will disperse into groundwater that is unpotable. In this paper we report the results of an investigation of a site where wastewater has been disposed of in the manner suggested by McCarthy et al. (1994) over a period of five years. The fate of bacteria present in the wastewater was also investigated during the study.

\section{Methodology}

\section{The study site}

The site chosen for the study was Chitabe Safari Lodge, situated in the seasonal swamps in the southeastern portion of the Okavango Delta (Fig. 1) on Chitabe Island. The island is oval in shape, about $800 \mathrm{~m}$ long and $250 \mathrm{~m}$ wide. A perennial stream flows along the south-western side of the island,

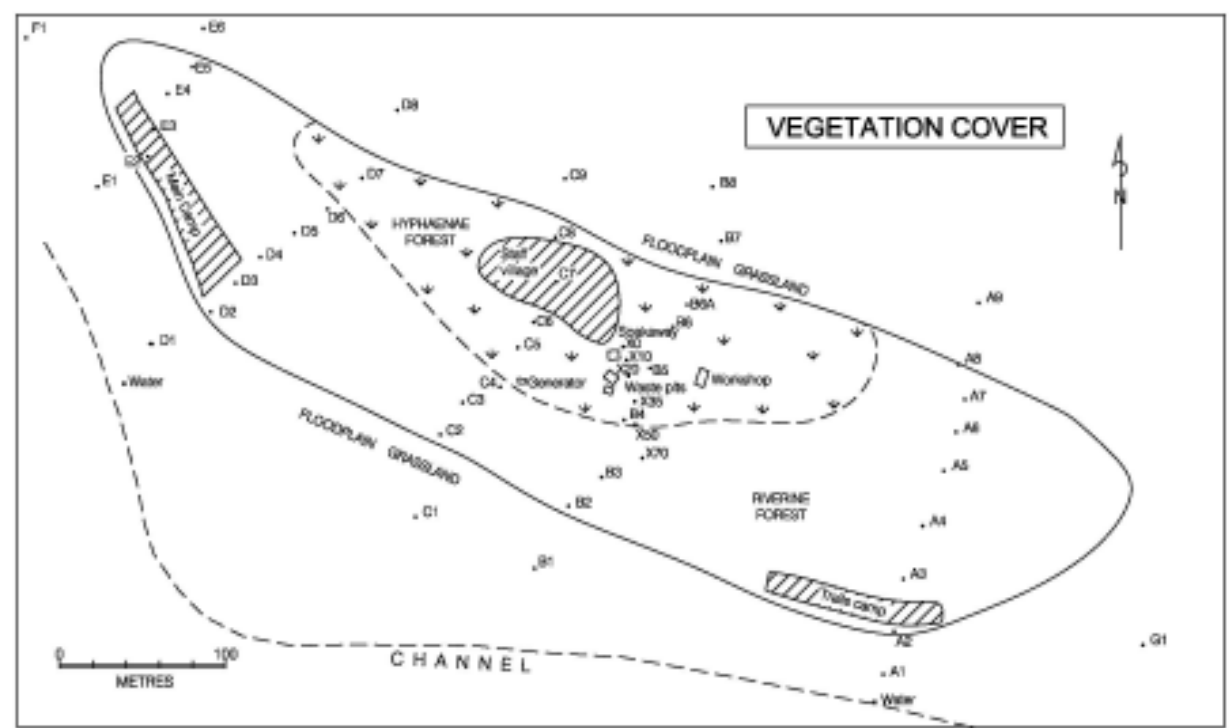

Figure 2

Map showing the vegetation types and major structures on Chitabe Island. The locations of survey transects and groundwater sampling sites are also shown. 
while the north-eastern side faces an extensive flood plain, which receives water for about 4 months during the winter. Peak flooding occurs in July or August. Chitabe Island is densely vegetated by riverine forest on its south-western side, but this gives way to hyphaenae palm forests along portions of the north-eastern side (Fig. 2), indicative of saline groundwater (Ellery et al., 1993). The lodge consists of two separate camps. Main Camp, situated in the forest fringe on the north-western side of the island, has 8 2-bed units, each with its own ablution facilities, and separate septic tank and soak-away. Trails Camp, on the southeastern side of the island, has $5 \times 2$-bed units, each with separate ablution facilities and septic tanks. The camps obtain their water from two boreholes, located close to the stream to the southwest of the island. Most of the staff is accommodated in the staff village, and share common ablution facilities, with a single soak-away (Fig. 2). During the initial survey, this soak-away consisted of a simple rectangular hole in the ground, which received outflow from the two-chambered septic tank. This was re-

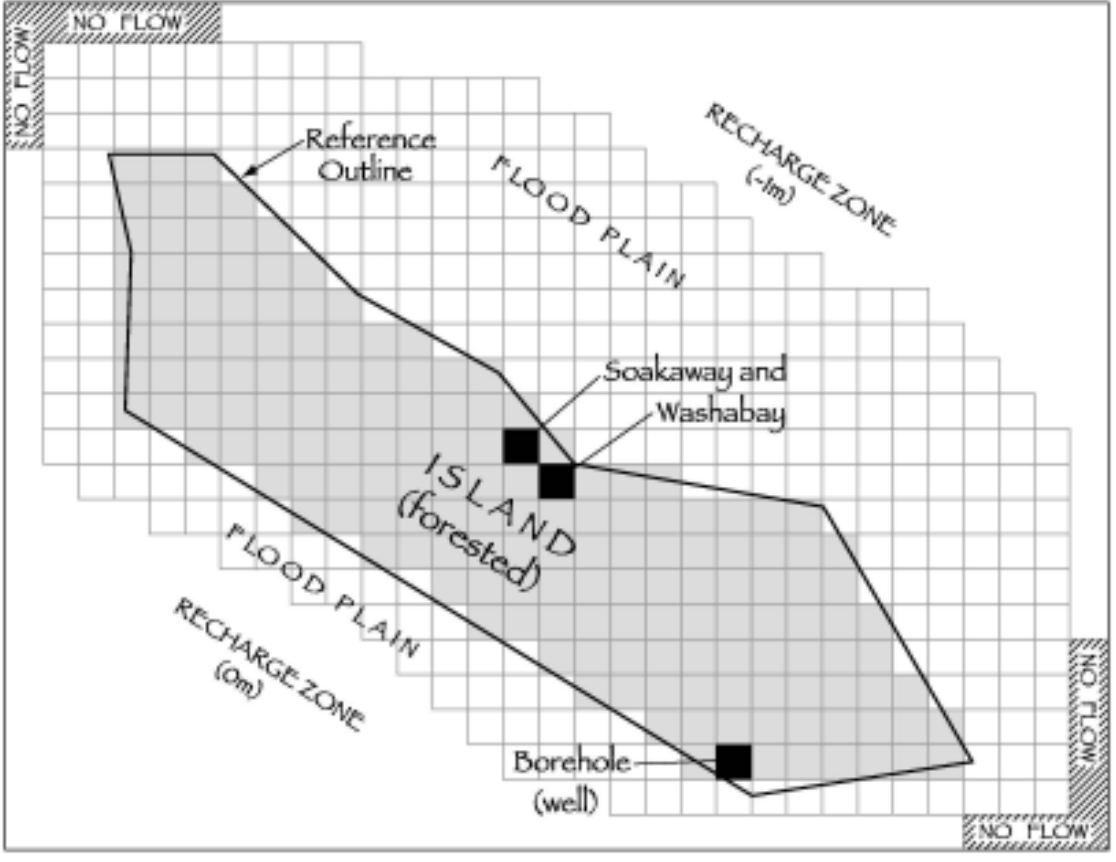

Figure 3

Configuration of the hydrological model used to assess groundwater flow. See text for details. placed by a chevron pattern of perforated

piping buried about $1 \mathrm{~m}$ on average below surface prior to the second visit. The resident population in the village is 33 persons. Assuming that each person uses $200 \ell$ of water per day, the soakaway disposes of about $6.5 \mathrm{~m}^{3}$ of wastewater per day. In addition, there is a vehicle wash-bay next to the soak-away, where the five safari vehicles are washed twice per day. The study was focused primarily on the region around this soak-away where maximum pollution would be anticipated. Management staff occupy dwelling units which are widely scattered over the island, each with their own ablution facilities and septic tanks.

\section{Topographic and groundwater table survey}

Topographic elevation was measured along five transects across the island, height being expressed relative to an arbitrary local datum (January water level in the channel to the south-west of the island). Auger holes were made to the groundwater table along the transects (Fig. 2), and depth to the water table was measured on two occasions, in January 2001 and July 2001. The electrical conductivity of groundwater was measured using a portable Hanna conductivity meter. The groundwater table was again surveyed along portion of transect B in June, 2002, and conductivities of groundwater samples collected at the water table and up to $4 \mathrm{~m}$ below the groundwater table were recorded. These deeper groundwater samples were obtained by inserting a steel casing to a depth of $6 \mathrm{~m}$ below surface, and then feeding a narrower sampling probe through the casing to project about one metre below its base. Groundwater was pumped from the probe for a period of $1 \mathrm{~h}$, by which time the conductivity had stabilised.

\section{Measurement of hydraulic conductivity}

Hydraulic conductivity of the island soil was measured using a constant head permeameter. For this purpose, auger holes were made to between $250 \mathrm{~mm}$ and $500 \mathrm{~mm}$ deep in the unsaturated zone, and were filled with water to a depth of about $150 \mathrm{~mm}$. After allowing time to equilibrate (generally about $15 \mathrm{~min}$ ), infiltration was measured, while maintaining the water depth in the holes.

\section{Hydrological modelling of groundwater beneath the island}

Three-dimensional groundwater flow modelling was carried out using the MODFLOW finite difference groundwater model (McDonald and Harbaugh, 1988), via the PMWIN interface of Chiang and Kinzelbach (2001). Flow paths were modelled using the PMPATH advective transport model (Chiang and Kinzelbach, 1994), also via PMWIN.

For the purposes of the models, a 31 x 24 cell grid was used, with cell dimensions of $25 \mathrm{~m} \times 25 \mathrm{~m}$ (Fig. 3). The depth of the aquifer was set to $40 \mathrm{~m}$, with the island elevated $2 \mathrm{~m}$ above water level along its centre, and $1 \mathrm{~m}$ on the rim. The flood plains to the south-west and north-east were set at a constant head of $0 \mathrm{~m}$ and $1 \mathrm{~m}$ respectively. The south-eastern and north-western boundaries were set as no-flow boundaries. Precipitation and evapotranspiration on non-forested areas were assumed to cancel each other out. Evapotranspiration from the forested island was assumed to have a maximum rate of $5 \mathrm{~mm} \cdot \mathrm{d}^{-1}$ (equivalent to an annual rate of 1825 $\mathrm{mm}$ ), with a linear decline to an extinction depth of $5 \mathrm{~m}$ below surface, representing the root zone of the trees on the island. Horizontal hydraulic conductivity was set to $0.7 \mathrm{~m} \cdot \mathrm{d}^{-1}$, and effective porosity to $20 \%$. These parameters defined the basic model.

To simulate the effect of water abstraction and disposal, wells were introduced into the basic model (Fig. 3). Water abstraction from a well near the edge of the island (which represented one of the boreholes) was set to $20 \mathrm{~m}^{3} \cdot \mathrm{d}^{-1}$, and two soak-away points were assumed, each consuming $10 \mathrm{~m}^{3} \cdot \mathrm{d}^{-1}$. One of these represented the soak-away from the staff village, and the other the vehicle washbay.

The seasonal effects on the water table were modelled by introducing two seasons: a winter period with evapotranspiration set to $4 \mathrm{~mm} \cdot \mathrm{d}^{-1}$ in the forest and $1 \mathrm{~mm} \cdot \mathrm{d}^{-1}$ in the grassland (extinction 


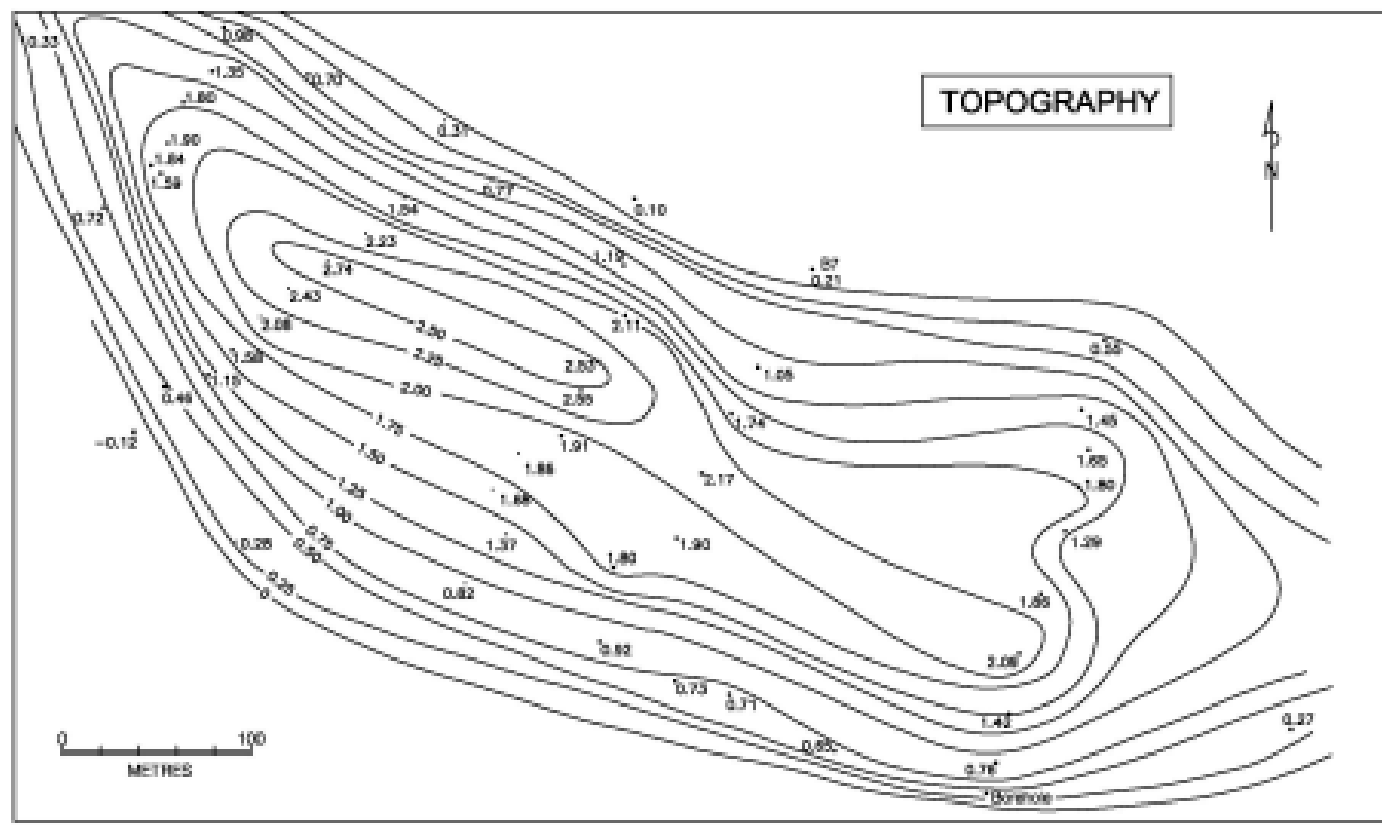

Figure 4

Topographic map of Chitabe island.

Elevations in metres.

Datum is surface water level in January 2001.

depth $2 \mathrm{~m}$ ); and a summer period with evapotranspiration set to 7.5 $\mathrm{mm} \cdot \mathrm{d}^{-1}$, with a net recharge over the forest and grassland of 1.5 $\mathrm{mm} \cdot \mathrm{d}^{-1}$. Evapotranspiration over the grassland in summer was assumed to be balanced by rainfall (average precipitation is 490 $\mathrm{mm}^{\prime} \cdot \mathrm{yr}^{-1}$, all falling in the summer months). The conditions used in these models straddle the basic model described above which was used to simulate the soak-away.

\section{Bacteriological screening}

The study site is very remote and the climate hot, with minimal refrigeration facilities en route, and accordingly it was deemed necessary to carry out the bacteriological screening on site. This strategy was also not without its difficulties, as the transport of equipment and reagents necessary to support conventional tests was out of the question. We required a simple test that could be carried out under relatively primitive field conditions. For this purpose we chose to use the Petrifilm ${ }^{\mathrm{TM}}$ (3M St Paul Minnesota; product codes 6400/6406 and 6404/6414) technique for the tests. Although primarily designed for testing food products rather than water, the simplicity of the method under adverse field conditions outweighed the sacrifice in sensitivity in testing for coliforms and E. coli.

A line of auger holes (prefixed X in Fig. 2) was made extending outwards from the soak-away, and perpendicular to the depth contours of the groundwater table in this localised area in order to obtain groundwater samples for bacteriological testing. The closest hole was made within the chevron of wastewater disposal pipes in order to obtain samples of the groundwater directly beneath the disposal point. Water samples were extracted from the auger holes by means of a sampling bucket attached to a long pole. Any sediment present in the collected sample was allowed to settle for a few minutes, and the supernatant liquid decanted for testing. Water samples were also collected at the two supply boreholes, from the swamp on the south-western side of the island, and from the septic tank outflow.

Borehole water, swamp water and groundwater samples were tested neat and at dilutions of $10^{-1}, 10^{-2}$, and $10^{-3}$, while septic tank water was tested at dilutions of $10^{-2}, 10^{-3}, 10^{-4}$, and $10^{-5}$. After dilution, aliquots were placed on Petrifilm ${ }^{\mathrm{TM}}$ plates, left for $5 \mathrm{~min}$ to set, and then placed into plastic containers with sealing lids, and incubated for $48 \mathrm{~h}$. Thereafter the plates were read. All tests were duplicated. Total plate, coliform and E. coli counts were determined according to the manufacturer's instructions.

\section{Results and discussion}

\section{Observed condition of the groundwater}

The topography of the island is shown in Fig. 4. The island is oval in shape, and rises to a maximum height of $2.7 \mathrm{~m}$ above datum. Depth to the water table beneath the island in January 2001 is shown in Fig. 5a, and in July in Fig. 5b. The surface water level rose by $170 \mathrm{~mm}$ between January and July. The water table slopes away from the permanent channel along the south-western margin of the island, and the slope on the water table is steeper during the January period. In both January and July there is a distinct groundwater mound about 200 to $300 \mathrm{~mm}$ high around the region of the village soak-away and the vehicle wash-bay. The mound is a clear indication of recharge from local surface sources.

The salinity of the groundwater, as reflected by its electrical conductivity, is shown in Fig. 6. Salinity of the groundwater varies by more than two orders of magnitude, from a low of $0.12 \mathrm{mS} \cdot \mathrm{cm}^{-1}$ to a high of $14.8 \mathrm{mS} \cdot \mathrm{cm}^{-1}$. The saline groundwater is confined to an elongate zone towards the north-eastern margin of the island. The salinity gradient is far steeper beneath the north-eastern side of the island, where the groundwater salinity rises by almost two orders of magnitude over a horizontal distance of just $50 \mathrm{~m}$. There is some evidence of a slightly lower conductivity in the groundwater mound near the soak-away, and the conductivity falls from 10.9 $\mathrm{mS} \cdot \mathrm{cm}^{-1}$ (at Site B6) to $8.2 \mathrm{mS} \cdot \mathrm{cm}^{-1}$ (at Site B5), which could be due to dilution (borehole water has a conductivity of between 0.08 and $\left.0.12 \mathrm{mS} \cdot \mathrm{cm}^{-1}\right)$. There is an apparent inconsistency between the water table and the salinity data, in that the region of highest salinity lies on a sloping groundwater surface, and not in a groundwater depression. The possible cause of this will be discussed later.

The sampling of groundwater at the water table and at depth below the water table along transect B (Fig. 7) in June 2002 reaffirmed the steep salinity gradient on the north-eastern side of the island, and also revealed that maximum salinity occurs where 
the water table is lowest. At sampling Sites B6 and B6A fairly steep vertical salinity gradients were encountered, and at Site B6A in particular, conductivity rose from $14.9 \mathrm{mS} \cdot \mathrm{cm}^{-1}$ at the water table to $17.0 \mathrm{mS} \cdot \mathrm{cm}^{-1}$ at a depth of $3 \mathrm{~m}$ below the water table. The lower salinities towards the water table may be due to dilution by wastewater, although it should be noted that most of the wastewater is discharged in the vicinity of Site $\mathrm{B} 5$, where the vertical gradient is small. The vertical gradients could also be an inherent feature of the groundwater chemistry. Additional work would be needed to resolve this issue.

\section{Results of groundwater models}

The permeameter measurements of hydraulic conductivity yielded fairly consistent results that averaged $0.1 \mathrm{~mm} \cdot \mathrm{s}^{-1}$, or about $0.9 \mathrm{~m} \cdot \mathrm{d}^{-1}$. Hydrological models run using this value failed to produce any draw-down of the water table under the island, indicating that the value is too large. Several models were run using lower values, and it was found that results resembling the drawdown conditions observed in the field required a hydraulic conductivity an order of magnitude smaller than that measured. This suggests that the equilibration time allowed during the permeameter measurements was too short, and the high value obtained probably reflected mainly capillary effects around the measuring holes. The smaller value was used in the models. Results derived from the basic model are illustrated in Fig. 8, and fairly accurately reproduce the measured groundwater surface beneath the island (Fig. 5).

The change in the water table as a function of season is shown in Figs. 9a and b. During the summer, evapotranspiration is high, but there is some recharge from rainfall, and the draw-down forms an elongated depression situated under the island, but displaced to the northeast. During winter, this depression migrates further to the northeast off the island. In effect, there is a seasonal oscillation in the position of the groundwater depression. The salinity maximum represents water that has experienced most evapotranspirational loss over many migration cycles, and its position probably represents a time-averaged location of the maximum drawdown. Neither of the two measurement periods in 2001 coincided with maximum draw-down conditions. This may be the explanation for the inconsistency between the water table and the zone of maximum salinity referred to above. The very steep salinity gradient in the groundwater along the north-eastern side of the island may also be due to this oscillation, in which recharge from the flood plains to the north-east is essentially compressing saline groundwater which is being generated in the riparian fringe along the southwestern side of the island. It is noted that during the June 2002 measuring period, maximum salinity coincided with the maximum groundwater

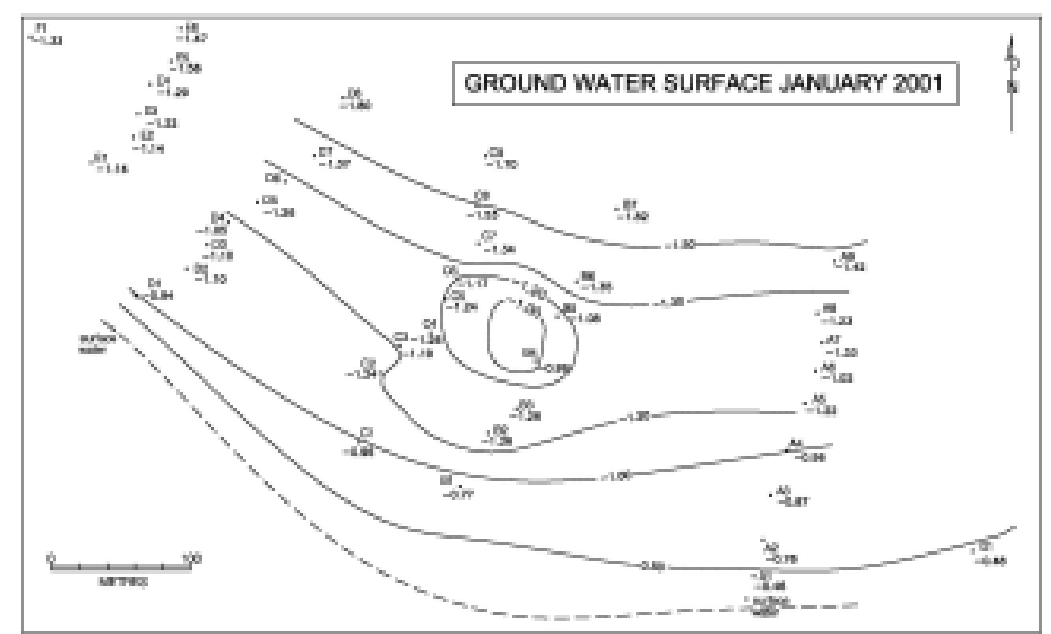

Figure 5a

Water table elevation in January 2001. Elevations in metres. Datum is surface water level in January 2001.

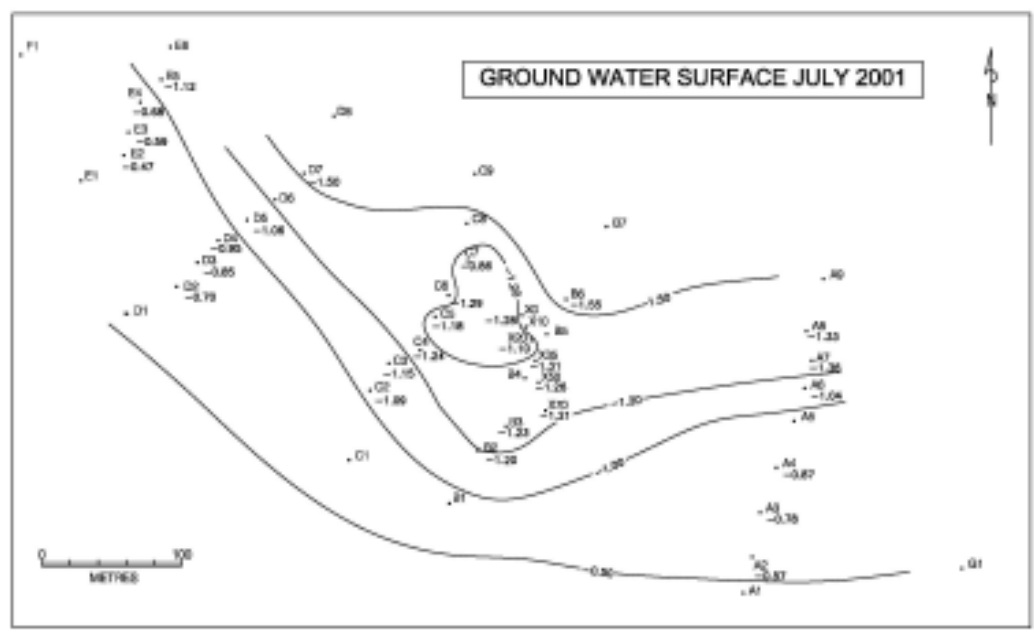

Figure $5 b$

Water table elevation in July, 2001. Datum is surface water level in January 2001.

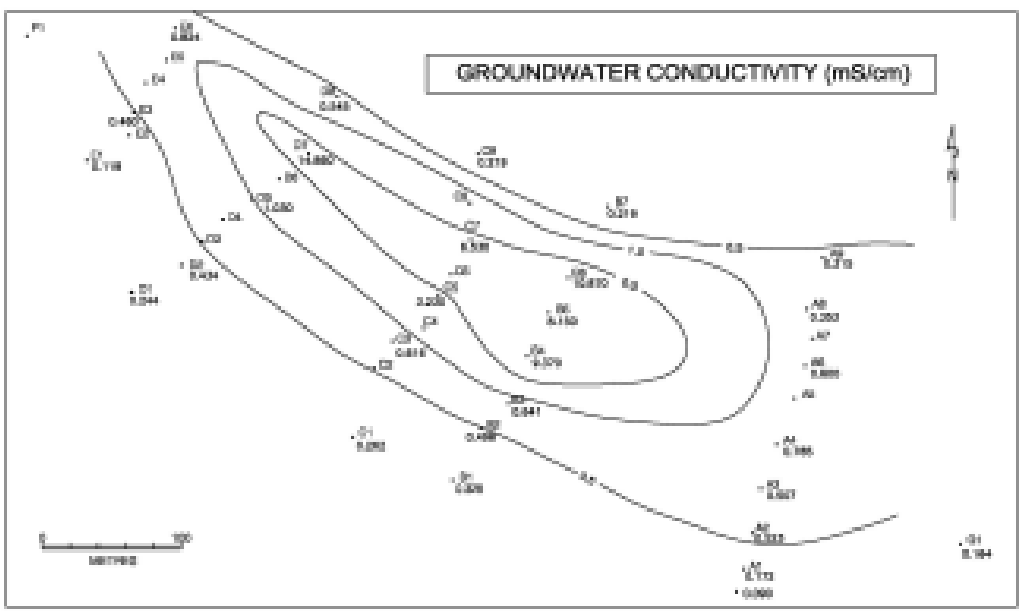

Figure 6

Electrical conductivity (in $\mathrm{mS} / \mathrm{cm}$ ) of the groundwater, sampled at the water table. 


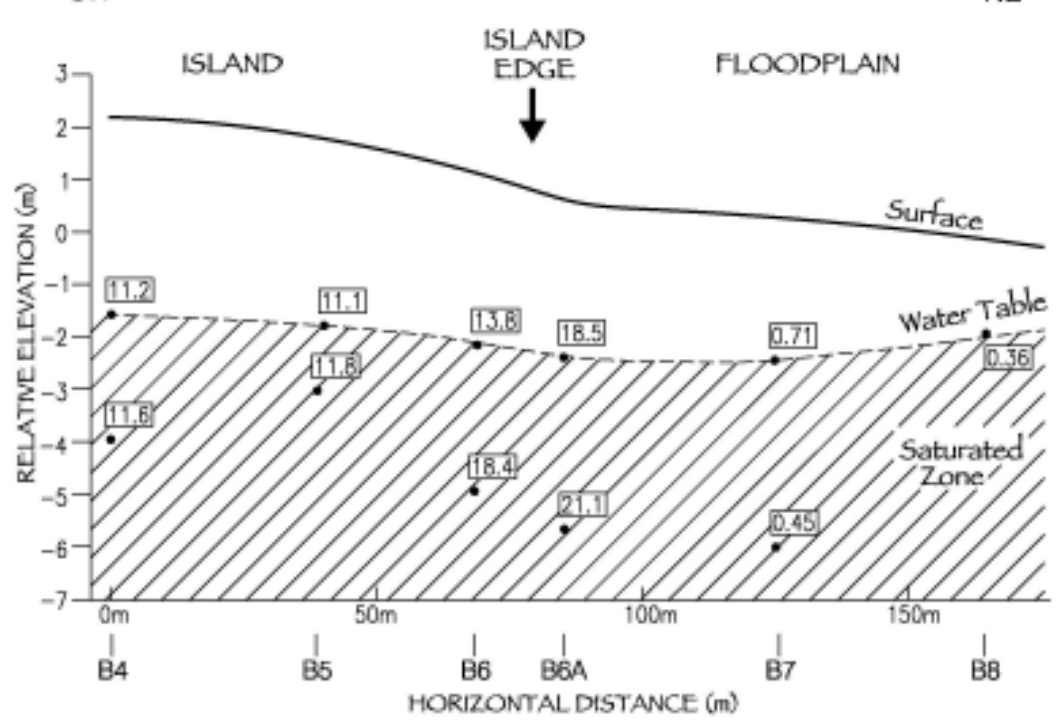

- 11.2 Groundwater conductivity (mS/cm)

Figure 7

Variation of the conductivity (in $\mathrm{mS} / \mathrm{cm}$ ) of the groundwater as a function of depth below the water table along transect $B$ in June, 2002. Elevation datum is surface water level in January 2001.

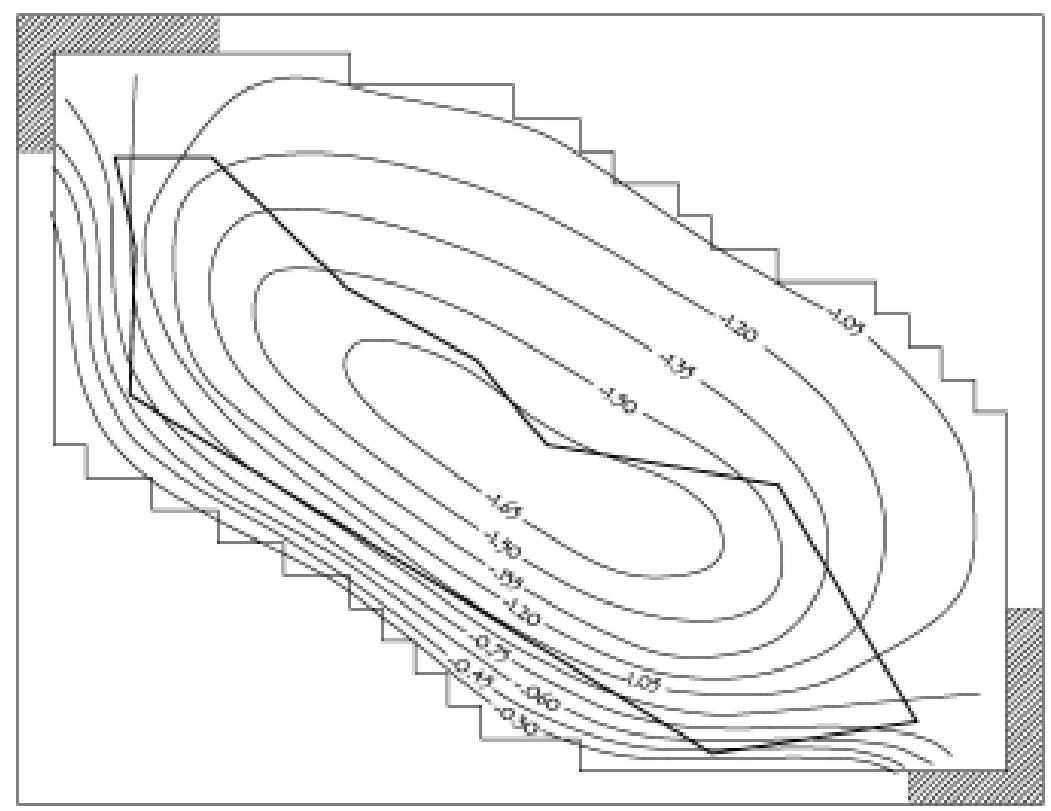

Figure 8

Results of the basic groundwater model. See text for details. Water table elevation contours in metres relative to surface water level southwest of the island.

depression (Fig. 7). At this time, the seasonal flood had not yet reached Chitabe Island, and it probably coincided with the seasonal low. The water table was on average about $500 \mathrm{~mm}$ lower than in the previous measuring periods. The very steep salinity gradient on the north-eastern side of the island (Fig. 7) indicates that diffusion in the groundwater is exceedingly slow.

The introduction of two water discharge sources into the basic model (the village soak-away and vehicle wash-bay) caused the development of a distinct recharge mound some $200 \mathrm{~mm}$ high (Fig. 10), fairly accurately reproducing conditions in the field (Figs. 5a;b). The presence of a well pumped at the rate of $20 \mathrm{~m}^{3} \cdot \mathrm{d}^{-1}$ caused slight local draw-down (Fig. 10), but this did not extend more than two cells (i.e. $50 \mathrm{~m}$ ) from the well point. The reason for this small effect is that the well is located close to permanent surface water.

Particle track modelling of the region of the soak-away showed that material released in the vicinity of the soak-away remains confined, and cannot migrate towards the edge of the island where the well is located (Fig. 10). The hydraulic head associated with the soak-away is simply too small in relation to the overall evapotranspirational water loss from the island. There is therefore no possibility that polluted water from the soak-away could reach the borehole, irrespective of how long discharge occurred.

In addition to the major point source of the village soak-away and vehicle wash-bay, there are numerous other, far smaller sources of polluted water scattered particularly around the fringes of the island in the form of soakaways at individual dwelling units. Particle track modelling of these sources indicates that flow is in all cases towards the island centre (Fig. 10), and even point sources in the island fringe close to the borehole show trajectories towards the island centre. The possibility of pollution entering the borehole from these sources is therefore also remote, provided there is permanent surface water in the immediate vicinity.

\section{Bacteriological screening}

Swamp water yielded moderate total plate counts and coliforms, but $E$. coli was not detected (Table 1). Borehole water had lower total plate counts compared to swamp water and coliforms and $E$. coli were not detected. Bacterial counts were highest in the septic tank effluent. Groundwater collected at a depth of about $2 \mathrm{~m}$ immediately beneath the perforated pipe system of the soak-away (Table 1 , sample $\mathrm{X} 0$ ) showed substantially reduced total plate and coliform counts but only moderately reduced E. coli, compared to the effluent. By a distance of $20 \mathrm{~m}$ from the soak-away, both coliforms and $E$. coli had fallen to below the detection limit of the test method. Total plate counts also decreased with distance from the soak-away, but even at a distance of $70 \mathrm{~m}$ remained substantially higher than borehole water.

The absence of a marked cone of depression around the borehole in the hydrological model suggests that surface water probably contributes significantly to recharge around the borehole. The bacteriological test results therefore imply that the sandy soils remove the coliforms and substantially reduce the total plate count of surface water as it infiltrates. It should be noted, however, that the total plate 
count in borehole water is still above potable water quality standards, and for this reason, borehole water should be treated (disinfected) prior to distribution (this practice is followed at Chitabe Lodge).

A reduction in total plate and coliform counts was also observed beneath the soak-away, after the water had passed through no more than 2 to $3 \mathrm{~m}$ of soil. These results suggest that in spite of their sandy character, Okavango soils are nevertheless capable of a significant filtering effect on bacteria. Notwithstanding this apparent filtering effect, total plate counts at $70 \mathrm{~m}$ from the soak-away (Table 1 , sample X70) remain high compared to borehole water. This may reflect the migration of bacteria from the soak-away, but $70 \mathrm{~m}$ is about the limit of the recharge mound (Figs. 5a; b). High total plate counts in this sample may be related to the sampling methodology employed in this study. In making auger holes, it is impossible to avoid introducing soil material from the upper soil layers into the groundwater, and it is possible that the elevated total plate count in the groundwater at $70 \mathrm{~m}$ from the soak-away reflects contamination by soil bacteria.

\section{Conclusions}

The discharge of relatively large quantities of wastewater into the groundwater over a period of several years has produced a measurable recharge mound beneath the soak-away on Chitabe Island. The height of this mound (200 to $300 \mathrm{~mm}$ ) is, however, small in relation to the total drawn-down of the water table beneath the island (about $1.5 \mathrm{~m}$ ) due to transpiration by the vegetation. Moreover, it is also smaller than the seasonal fluctuation of the water table (about $500 \mathrm{~mm}$ ). The discharge of this water has resulted in only a small reduction in the electrical conductivity of the groundwater, suggesting that there is some mixing of the wastewater and the very saline groundwater.

Particle track modelling suggests that the major draw-down under the island is such that it confines pollutants to the immediate vicinity of the region of

Figure 9a (top right)

Results of the groundwater model for the summer months. Water table elevation contours in metres relative to surface water level south-west of the island.

Figure $9 b$ (middle right)

Results of the groundwater model for the winter months. Water table elevation contours in metres relative to surface water level south-west of the island.

Figure 10 (bottom right)

Results of the groundwater model including a soakaway and well. Modelled particle movements are also shown by arrows. Arrow length represents movement over a period of 10 years. Water table elevation contours in metres relative to surface water level south-west of the island.
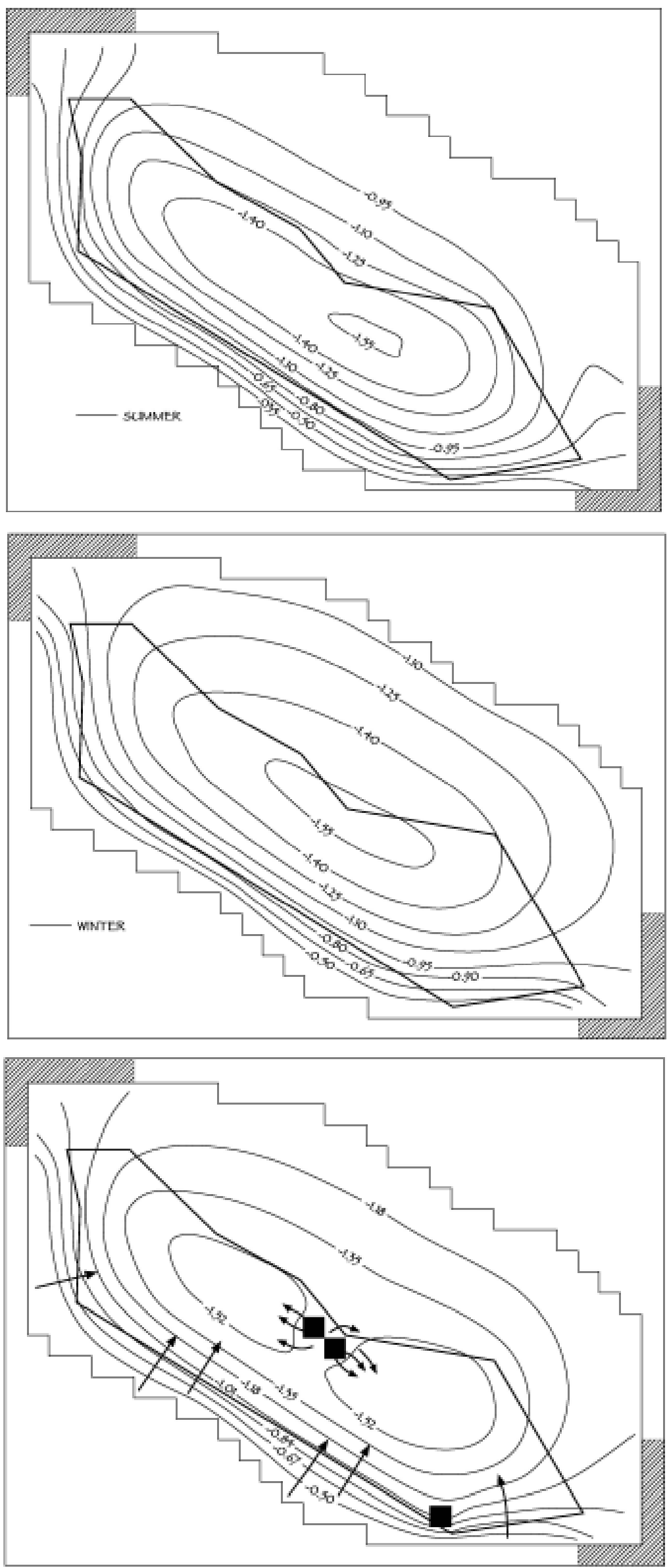


\begin{tabular}{|l|c|c|c|}
\hline \multicolumn{3}{|c|}{ TABLE 1 } \\
\hline \multicolumn{3}{|c|}{ Results of bacteriological screening } \\
\hline Sample description & Total plate count & Coliform count & E. coli count \\
\hline Swamp water & 626 & 300 & 0 \\
Borehole \#1 & 220 & 0 & 0 \\
Borehole \#2 & 230 & 0 & 0 \\
Septic tank & $4.7 \mathrm{~m}$. & innumerable & 310 \\
Groundwater X0, beneath soak-away & 221500 & 1800 & 200 \\
Groundwater X10, 10 m from soak-away & 213000 & 160 & 110 \\
Groundwater X20, 20 m from soak-away & 44300 & 0 & 0 \\
Groundwater X35, 35 m from soak-away & 68500 & 0 & 0 \\
Groundwater X50, 50 m from soak-away & 56800 & 0 & 0 \\
Groundwater X70, 70 m from soak-away & 9000 & 0 & 0 \\
\hline
\end{tabular}

maximum draw-down. Furthermore, the hydraulic gradient created by transpiration is such that flow paths from the low discharge soak-aways scattered around the island all trend towards the zone of maximum draw-down. The models also indicate that boreholes located on the outer fringe of the island, close to permanent water, generate limited cones of depression, and are secure from possible contamination from the soak-aways, as well as leaks from garbage disposal pits located near to the major soak-away.

Bacteriological screening indicates that the soils of the region are capable of significantly reducing bacterial loads by filtration, in spite of their sandy character. Although the assay method lacks sensitivity, results obtained with the Petrifilm method suggest that both E. coli and coliforms decline rapidly with distance from the discharge point and were not detectable at a distance of $20 \mathrm{~m}$ from the source.

This study has revealed that the notion of locating soak-aways above the salinised island interior can provide a sustainable solution to the problem of wastewater disposal at lodges in the Okavango Delta. Such areas of salinised groundwater can easily be located by inspection of the island vegetation. Hyphaenae palms (ivory palms) characterise areas of modest degrees of salinisation, while highly salinised areas are devoid of trees and support the very spiky grass Sporobolus spicatus. Modelling indicates that the possibility of pollution of borehole water is remote, provided the boreholes are located outside the densely forested island fringe. Every island is, of course, unique, but with careful inspection, optimal sites for water draw points and the disposal of wastewater can be located.

\section{Acknowledgements}

We thank Okavango Wilderness Safaris, and especially Paul and Sharene Kristafor and their staff at Chitabe Lodge for their support during this study, Mat Kitching, Piotr Wolski and Frank Seidel for help in the field, Mr T Govender of 3M South Africa for donating the Petrifilm ${ }^{\mathrm{TM}}$ media, and the Swedish Royal Academy of Sciences and the University of the Witwatersrand for financial support.

\section{References}

CRONBERG G, GIESKE A, MARTINS E, PRINCE-NENGU J and STENSTROM I-M (1995) Hydrobiological studies of the Okavango Delta and the Kwando/Linyanti/Chobe River, Botswana. 1. Surface water quality analysis. Botswana Notes and Records 27 151-226.

CHIANG WH and KINZELBACH W (1994) PMPATH for Windows. User's Manual. Distributed by Scientific Software Group, Washington DC.

CHIANG WH and KINZELBACH W (2001) 3D-Groundwater Modelling with PMWIN. Springer-Verlag, Berlin. 346 pp.

ELLERY WN, ELLER K and McCARTHY TS (1993) Plant distribution in islands of the Okavango Delta, Botswana: Determinants and feedback interactions. Afr. J. Ecol. 31 118-134.

McCARTHY TS, ELLERY WN and GIESKE A (1994) Possible groundwater pollution by sewage effluent at camps in the Okavango Delta: Suggestions for its prevention. Botswana Notes and Records 26 129-138.

McDONALD MG and HARBAUGH AW (1988) MODFLOW, A Modular Three-Dimensional Finite Difference Groundwater Flow Model. US Geological Survey, Open-file Report 83-875.

OLANREWAJU D (1990) Soak-away systems and possible groundwater pollution in developing countries. J. Royal Soc. Health $\mathbf{1 1 0}$ 108-112.

PARKER WF and MEE BJ (1982) Survival of Salmonella adelaide and fecal coliforms in coarse sands of the Swan Coastal Plain, Western Australia. Appl. Environ. Microbiol. 43 981-986.

WALL GJ and WEBBER LR (1970) Soil characteristics and subsurface sewage disposal. Can. J. Public Health 61 47-54. 